\title{
STRATEGIC RESPONSES IN CORPORATE TAX PLANNING USING OPPORTUNITY AREAS
}

\author{
Mykola Bondar \\ Kyiv National Economic University named after Vadym Hetman \\ 54/1 Peremogy Avenue, 03057 Kyiv, Ukraine, mykola.bondar@kneu.edu.ua \\ (D) https://orcid.org/0000-0002-1904-1211 \\ Oksana Portna* \\ V.N. Karazin Kharkiv National University \\ 4 Svobody Sq, 61022 Kharkiv, Ukraine, portna@karazin.ua \\ https://orcid.org/0000-0002-8803-4605 \\ Natalia lershova \\ National Technical University "Kharkiv Polytechnic Institute" \\ 2 Kirpichov St, 61000. Kharkiv, Ukraine, iershova@kpi.kharkov.ua \\ https://orcid.org/0000-0003-3544-3816
}

Article history: Received 19 July 2021, Received in revised form 10 August 2021, Accepted 10 August 2021, Available online 10 August 2021

\begin{abstract}
Using sampling for companies from EU member states and Ukraine, we find a significant and positive relationship between the company size and the amount of corporate taxes. We use questionnaires to determine the role of corporations in expanding the scope of tax management and discover an increased effect of corporate planning. Moreover, we offer a model of corporate tax planning considering the opportunity areas. This model determines the taxation framework for a company. We have developed a map to determine the degree of effective tax planning for a company. Finally, we use the functional-activity model of the tax planning process to substantiate the conclusion that the responsibility of the participants in such a process stipulates good business reputation. In general, our results suggest that corporate tax planning is an effective way to optimize tax liabilities.
\end{abstract}

\section{Keywords}

tax planning, tax policy, taxation, zones of opportunity, development strategy, corporate responsibility

\section{Introduction}

The substantive characteristics of such concepts as 'development', 'profitability', and 'taxation', their ontological basis, subordination and interrelation with other concepts of the productive continuum determine the features of corporate management and tax planning to develop algorithms for the upward movement of companies. Tax relations are formed between the state and taxpayers and are at the intersection of public interests of the state and private interests of taxpayers. They are an integral part of social responsibility. Thus, the state is interested in replenishing the relevant budget, while taxpayers focus on reducing deductions from their income. Is there a conflict of interest? Definitely. Tax policy is formed at the state level. The European Union's policy on direct taxes is aimed at providing a level playing field for companies to ensure healthy competition and create a favourable tax environment. In general, EU countries seek to standardize tax rates and oblige companies to pay taxes exactly where they make a profit. According to analytical data and statistical observations, the standard VAT rate fluctuates in European countries. Thus, in Switzerland it equals 7.7\%, whereas in Germany the standard VAT rate is $19 \%$. Estonia and France account for $20 \%$ while the Czech Republic, Lithuania, and Latvia have the VAT rate as high as $21 \%$. In Poland and Hungary it comes to $22 \%$ and $27 \%$ correspondingly. The income tax rate in Hungary is $9 \%$ while Switzerland has $8.5 \%$ (federal tax rate) plus a cantonal tax. In Germany it accounts for $15 \%$, whereas in Poland and the Czech Republic the income tax rate comprises 19\%. In Slovakia this figure is as high as $22 \%$. What is more, the tax base is different in the countries. The list of countries by tax rate is shown in Fig. 1. 


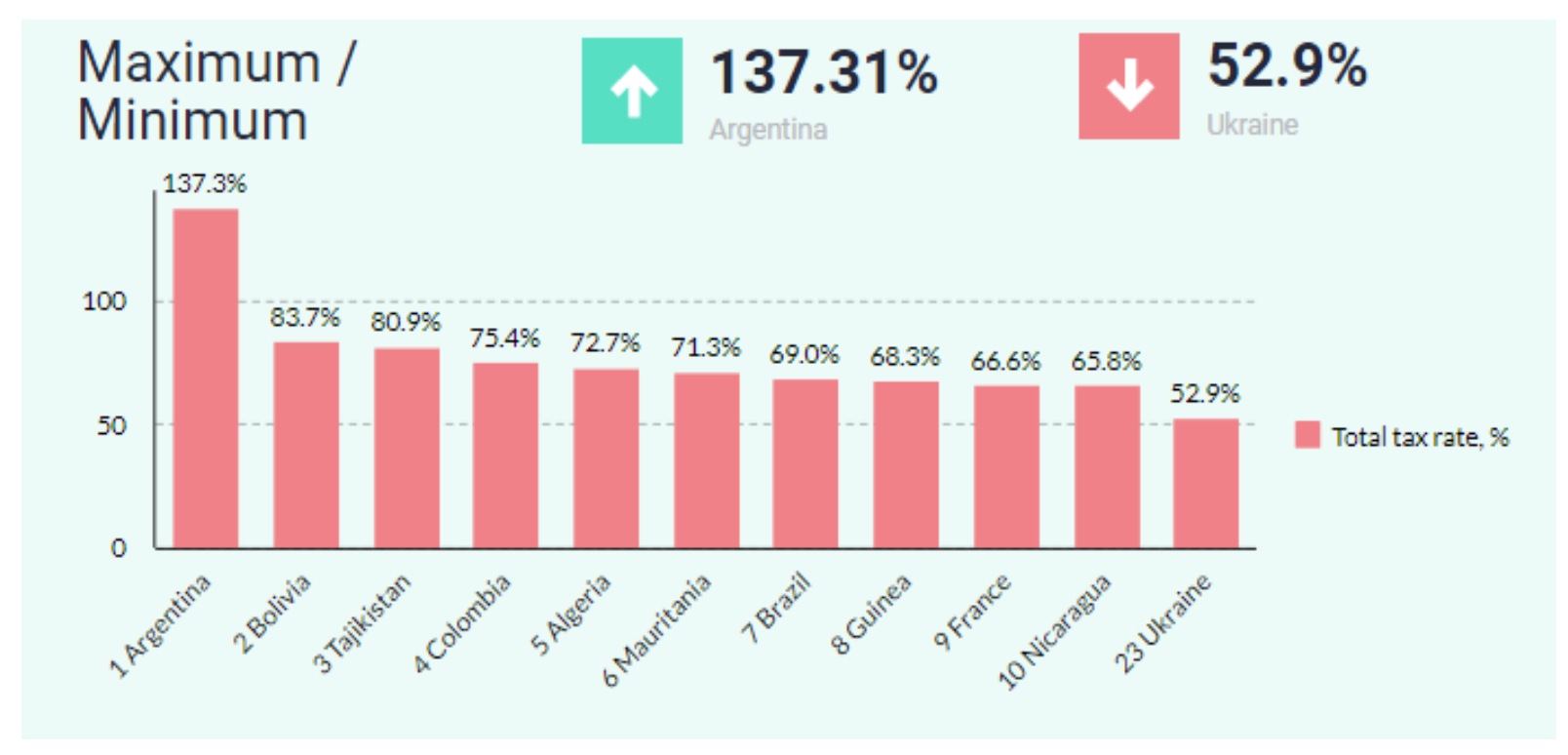

Fig. 1. Country Ranking: The Highest Tax Rates (by the Total Tax Rate). Source: Compilation based on [1]

One of the EU criteria that determine the need to pay income taxes are the degree of economic relations between the potential taxpayer and the state. For 2021, the European Commission has approved an agreement of finance ministers of the world's seven most industrialized economies on the introduction of income tax rate on large corporations of at least $15 \%$. According to EU statistics, this will increase annual revenues to its budget by 50 billion euros [2].

Taxes have a significant impact on the financial and economic activities of companies. Therefore, the scientific discussion takes place at the intersection of tax planning, financial management, accounting, corporate governance and corporate social responsibility. Thus, researchers [3] conclude that trade-off, hierarchy and theories of free cash flow play an important role in explaining the monetary determinants of companies, influencing the strategy of tax planning and corporate management. In this aspect, draw your attention to the research results on corporate financial indicators as well as their impact on corporate governance and calculation of tax payments [4]. Depending on the scale and financial capabilities, scientists [5] recommend using different models of tax management - from the simplest, which are reduced to tax accounting or tax planning, to complex ones that cover the full range of tax management tools such as tax planning, tax analysis, monitoring of business transactions, tax accounting and reporting, and tax control. A number of instruments such as analytical, normative, statistical ones and a balance sheet are defined as legitimate (by Suchman [6]) just as special methods of tax planning, i.e. methods based on tax benefits and alternative tax solutions are. The emergence of numerous innovative technologies on the market, including financial and monetary technologies and new products causes a need to regulate the taxation system at all levels [7].

Previous studies discovered a relationship between the values of financial indicators and the reporting system of companies [8]. Due to different approaches to reporting, some of its articles change, which is the reason for achieving different values of financial indicators [9]. This has an impact on the amount of taxes. When linking tax planning and financial indicators, there is a negative impact of tax planning on liabilities $[10,11]$. Therefore, the management of companies resort to different methods of optimizing tax liabilities, including illegitimate tools, i.e. tax evasion or tax avoidance, and legitimate methods such as tax planning [12].

Domestic stakeholders are interested in conducting tax planning in companies due to the impact on the company's reputation as a social [13], and economic [14] phenomenon. At the same time, researchers [14] note the importance of the information and its impact on the practice of tax planning. However, domestic stakeholders sometimes have an adverse response to tax planning due to the expected significant operating costs [15]. Studies by Landolf and Hartnett on tax planning in the corporate governance system are of scientific and practical interest $[16,17]$. In implementing tax planning Landolf identifies the following benefits for 
corporations: business planning of tax payments, formation of tax calendars, submission of tax reporting, objective choice of methods and tools for tax optimization. Feller \& Schanz complement the body of knowledge by providing empirical evidence of the impact tax planning has on the assessment of corporate social responsibility. In this case, other stakeholders (tax authorities) can obtain information on the potential risks of tax planning of the corporation through activities in the field of corporate social responsibility [18].

Academic research in the field of corporate tax planning is expanding along with the growing public interest. In addition, increased scientific attention to the issue of corporate tax planning in connection with strategic development was facilitated by the processes of globalization and internationalization which raised the problem of integration of national tax systems into the world economy. The results of the study [19] confirm the importance of strategic interaction with business partners; and the impact of such interaction on the amount of tax liabilities is important.

Tax regulation still varies from country to country, including the European Union, although countries aim for a policy of general harmonization. Thus, in Ukraine, the highest state body has the right to impose taxes whereas in Switzerland taxes are set by cantons (regions) regardless of the highest authority. Led by the desire for European integration, Ukraine has reduced the number of taxes. This reduction is not a cut-down or abolition of certain types of taxes but their certain combination. That is, the results of such a decision do not change the burden on taxpayers. In Poland, in 2020, personal income tax was calculated at a rate of $18-32 \%$, while income up to PLN 8,000 was not taxed. In Switzerland, the federal tax rate was up to $11.5 \%$ plus a cantonal tax, with the $12.20 \%$ effective personal income tax rate in the canton of Geneva for the income of $\mathrm{CHF} 6,000$ per month and 26.15\% for the income of CHF 20,000 per month. Tax rates in EU member states for legal entities are as follows. In 2020, the value added tax rate in Switzerland was 7.7\%, however, it comprised $2.5 \%$ for basic necessities and $3.7 \%$ for the hotel business. Banking service, insurance premiums, residential real estate, educational and medical services regulated by the casino are not taxed. The value added tax rate in Poland was $23 \%$, with $0 \%$ for exports to countries outside the EU; $5 \%$ for books, magazines, basic foodstuffs; $8 \%$ for pharmaceutical products and passenger traffic. Financial, insurance and educational services were not taxed. Also, the legislation of the countries provides for various tax benefits if companies will operate in areas approved by public authorities [2].

When studying the concept of corporate taxes, Jacob [20] identifies the real effects of corporate taxation and they have a significant impact on the income and profits of companies. The scientist concludes there is a consensus that higher corporate tax rates reduce corporate investment, foreign direct investment, aggregate growth and innovation.

The concept of tax planning is developed in the direction of corporate social responsibility. Elgood et al. [21] consider this direction when determining the unique tasks of tax departments. Such tasks include creation, protection and optimization of value; management of tax risks associated with doing business; ensuring compliance with tax laws and reporting requirements. The authors conclude that tax planning should focus on optimizing financial results and tax risks, both in relation to strategic agreements and current operations.

The work of Rashid et al. [22] aimed at establishing a link between financial performance and the level of tax expenditures in the model of internal tax planning. Using the method of integrated regression model, OLS can act as a special method of tax planning of the company.

In his doctoral project Princen [23] developed the theory of corporate planning through the influence of taxation on corporate financial decision-making. This approach is justified in the study through tax optimization. The author argues that the use of tax planning strategies has a significant impact on financial and investment decisions of the company.

Scientific and practical interest in corporate tax planning in recent years is also explained by the fact that the general public awareness of corporate tax activity is increasing. At the same time, increased efficiency of crisis management of companies during the COVID-19 pandemic is coupled with the effectiveness of financial and accounting instruments in relation to taxes [24]. In our opinion, the relevance of further research on this problem is due to its multifaceted nature. And it is also coupled with the fact that as a process tax planning is influenced by many economic and social factors and governed by macro- and macro-level factors. In our opinion, tax 
planning is a kind of tool that allows you to choose the most effective way of tax activities of the company and create directions for its development strategy.

This article contains new ideas on corporate tax planning. The strategic consequences of its implementation in corporations will also be discussed regarding the actions on preventing violations of public interest when outlining the boundaries of tax planning. Areas of opportunity are also defined by the participants of tax planning in the corporation and through the scope of their corporate responsibility.

The purpose of this article is to develop an innovative approach to corporate tax planning considering areas of opportunity. Recognition of its locus in the corporate tax management system and implementation will optimize the taxation system, maximize the income and profits of companies and increase financial stability.

\section{Methods}

The corporation as an organisational and legal form of management expands the scope of tax management and responsibility for forecasting tax expenditures and control over their payment. At the same time, a wellestablished tax planning process can have a significant impact on a company's success both economically and socially. The current study attempts to analyse tax planning in its general context, i.e. without dividing actions into tax evasion and avoidance.

The sample for this study is represented by agricultural corporations in Ukraine. The research period is the effect of Legislative Acts of Ukraine regarding taxation in 2019-2020. Data for branch analyses are retrieved from the statistics collected and disseminated by the State Statistics Service of Ukraine. We use statistical methods to grade agribusiness corporations in Ukraine in terms of their revenue and to assess the dynamics of output and its distribution among companies operating in the sector of Ukrainian agriculture. The study carries out an interview to determine the main advantages of corporate organisation of economic activity in the opinion of middle and senior managers. Number of respondents, $\mathrm{N}=45$ people from 20 companies, including 31 middle and 14 senior managers. We used the method of legislative review to establish the tax rate in the agricultural sector. The assessment of statistical data was carried out to group taxes by structure and amounts paid by Ukrainian agricultural enterprises to the budget (for the period of the first half of 2019). A model of corporate tax planning has been developed and presented using infographics. The successive stages are singled out and completed with tools and methods. We present the model implementation on the example of four Ukrainian agribusiness companies. In this study analytical methods are used in the course of developing a taxation framework of an agricultural company regarding tax types, tax base, and tax rates. We control that the framework will be determined separately for each company, so we present a general section. The map for determining the degree of effective tax planning in the corporation was developed and presented in this study as a questionnaire. Emphasis is placed on the importance of the organizational component in the process of tax planning. Based on organisational modelling, the scheme of participants in the tax planning system in the corporation and the scope of their corporate responsibility are presented.

\section{Results and discussion}

Corporation as a structural element of the national economy: features of functioning and specifics of taxation The development of the national economy greatly depends on large enterprises (corporations), which occupy leading positions in manufacturing and sale of products and are developers of modern technologies, investors, etc. This is confirmed by statistics from many countries: the lion's share in the structure of national gross domestic product belongs to large corporations [25]. In general, increasing the number of corporations in Ukraine and in agriculture in particular is an important economic mechanism that creates new strategic goals of foreign economic policy, means and conditions for Ukraine's participation in the international division of labour and attracting foreign direct investment into the national economy.

The corporate sector of the Ukrainian economy is represented by joint stock companies, integrated formations, and non-joint-stock corporate sector [26]. The development of corporate relations in the Ukrainian agricultural sector is of particular importance as this industry receives significant flows of investment, including foreign one. Let us turn to statistics. In 2019, the 20 most profitable companies together received UAH 162 billion in net profit. This comprises $71 \%$ of the total profit received by the 200 largest Ukrainian companies in Ukraine in 2019. As for the agro-industrial complex, the 20 most profitable companies include the Myronivsky Khlibo product corporation with a profit of UAH 5 billion in 2019 [27,28]. The dynamics of output volume and its distribution among companies operating in the Ukrainian agricultural sector is shown in Fig. 2. 


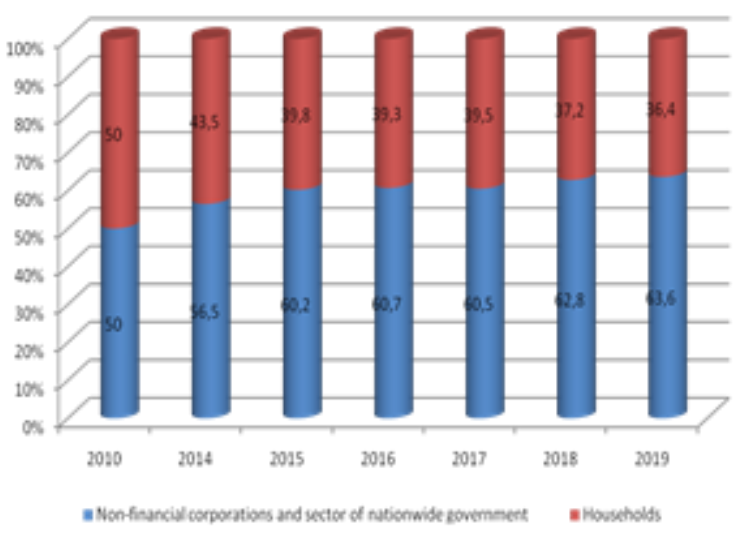

a) Output in Agriculture, percentage to total

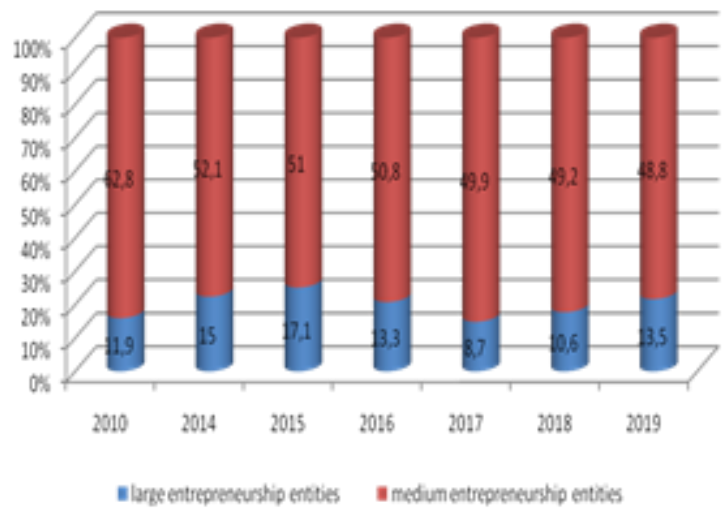

b) Turnover of business entities by Agriculture, in \% to the total of business entities

Fig. 2. The dynamics of output volume and its distribution among companies operating in the Ukrainian agricultural sector. Source: own study based on [27].

In the first half of 2019 companies in agriculture, forestry and fisheries paid taxes in the amount of UAH 21 billion 232 million 365.5 thousand (Table 1). In the first half of 2019, the agricultural sector ranks 11th in terms of the taxes paid. APK-Invest PJSC became the leader among agricultural enterprises [28].

Table 1. The structure and amount of taxes paid by agribusiness companies to the budget for the first half of 2019. Source: own systematizy based on [28].

\begin{tabular}{|c|c|c|c|c|c|c|c|}
\hline \multicolumn{7}{|c|}{ Structure and amount of taxes, thousand UAH } \\
\hline $\begin{array}{c}\text { PIT and } \\
\text { military } \\
\text { tax }\end{array}$ & $\begin{array}{c}\text { Income } \\
\text { tax }\end{array}$ & Rent & $\begin{array}{c}\text { Excise tax on } \\
\text { goods } \\
\text { produced in } \\
\text { Ukraine }\end{array}$ & $\begin{array}{c}\text { VAT on } \\
\text { goods } \\
\text { produced in } \\
\text { Ukraine }\end{array}$ & $\begin{array}{c}\text { Property } \\
\text { tax }\end{array}$ & Ecotax & Single tax \\
\hline 7571974.5 & 542436.4 & 642216.2 & 2473.4 & 8259366.8 & 2163171.0 & 41779.0 & 1793302.6 \\
\hline
\end{tabular}

Agricultural companies, like other entities, are looking for ways to optimize the tax burden. One of them is the introduction of tax planning which is an important element of the company's tax management system. Tax management aims to build the most optimal relations between the company and the state in the matter of tax calculation and payment. It is important to note that savings due to optimization of taxes and payments increase the entity's own financial resources. Therefore, the achievement of the main goals of entrepreneurial activity is ensured by increasing the level of income, financial stability and growing profitability.

This confirms the significant and positive relationship between the company size and the amount of taxes and a wide range of corporate opportunities for business organization through modelling inter-company relations. Given the cognitive potential, we conducted a survey of top and middle managers in the Ukrainian agricultural sector (number of companies, $n=20$ ). This provided an opportunity to model the main advantages of corporate organisation of economic activity based on the managers' opinion (the number of respondents is 45 , including 31 middle and 14 senior managers).

The following factors are defined as advantages:

- ability to raise funds through the issuance of shares, which allows the accumulation of funds of a significant number of investors ( $62 \%$ of the senior managers and $23 \%$ of the middle managers); 
- facilitation of business activity management through greater regulation in the definition of responsibilities and powers and distribution of the control function between the governing bodies ( $72 \%$ of the senior managers and $44 \%$ of middle managers);

- opportunities for stakeholder rotation and flexibility in terms of dynamic investment proposal (38\% of the senior managers and $13 \%$ of the middle managers);

- risk reduction due to the principle of limited liability ( $68 \%$ of the senior managers and $39 \%$ of the middle managers);

- others ( $23 \%$ of the senior managers and $14 \%$ of the middle managers).

Among the main negative consequences of tax rules for agricultural companies noted by the respondents are potential excessive tax regulation, high risk of double taxation, frequent changes in tax legislation and a significant tax burden. In this aspect, we note that the agricultural sector is sensitive not only to the level of taxes, but also to their combination. As of 2020, the tax legislation of Ukraine gives alternatives for agricultural companies in terms of the taxation system [29].

\section{$\underline{\text { Tax planning as a tool to improve business profitability: Analytical aspect }}$}

In this study, corporate tax planning is understood as a purposeful activity that involves assessing and making management decisions to justify and choose the option of paying taxes, which will optimize the tax system and maximize the income and profits of companies. We base this definition on an activity approach that allows us to outline the process of organizing tax planning in a corporation. The corporate tax planning model combines several stages and involves certain steps for its implementation (Fig. 3).

At the Preparatory Stage, the national taxation system, tax rates and amounts of tax payments are monitored. The dynamics of the company's activity (income from the main activity and related activities; the amount of costs from operating and other activities) is estimated. The tax burden is analysed. The taxation framework is assessed. Tax planning specialists analyse all the statutory benefits for each tax, which are applied to the company with respect to the activity size and type, and develop a detailed plan for the use of benefits for individual taxes, as well as analyse possible tax risks.

At the Analytical Stage, alternative tax activities are assessed. This is when we suggest compiling a table in the form that is designed to characterize the taxation framework of the entity. We also propose to form typical business transactions that will be implemented by the business entity. Indicator-markers are set on the basis of analytical plans for the volume of activity, level of profitability, and marginal tax burden. Achieving such indicators is the subject of taxation and other types of control (production control, financial control, etc.). At this stage, the entity's tax calendar is compiled for the current period taking into account tax liabilities, tax payment deadlines and tax reporting. This plan must be consistent with the entity's overall financial plan. For the purpose of further tax control, the scale of deviations of the corresponding indicators-markers is developed.

The Organisational Stage characterizes the assessment of tax accounting and reporting (determination of the tax base, calculation of taxes and payments, accounting and tax records, preparation and submission of tax reports) and determination of the tax burden level. It deals with the control over compliance with tax legislation and accounting policies, assessment of the tax plan implementation. Proper implementation and effectiveness of tax planning in the company depends on its organizational support. One of the factors of the efficient Organizational Stage of the offered functional model for corporate tax planning is the control carried out at the level of employees of Accounting and Finance Department. Such control involves assessing accuracy of accounting for taxable objects and calculations of individual taxes and fees, work on tax returns, timeliness of their payment and submission of tax returns to avoid penalties. In this aspect, it is important that the registration of actual business transactions must comply with applicable law. In our opinion, an important specialist in the organisational structure of corporations is a tax planning specialist who works in the Accounting and/or Finance Department. Such a specialist has the competence and knowledge of the national tax system, features and timing of paying taxes to the budget, fees and contributions to extra-budgetary funds, and the ability to make tax calculations and declarations. 
Every company has its individual approaches to tax planning since they are determined by the scale of activity, industry, type of activity, areas of opportunity. However, we propose a general model of tax planning, which combines several stages and involves certain steps for implementation. The model considers the principle of business continuity and focuses on the formation of the tax field to minimize the tax base for individual taxes or payments. Every company sets the tasks of tax planning and solves them using the ways that do not violate an applicable law.

\section{$\Rightarrow$ Model of Corporate Tax Planning}

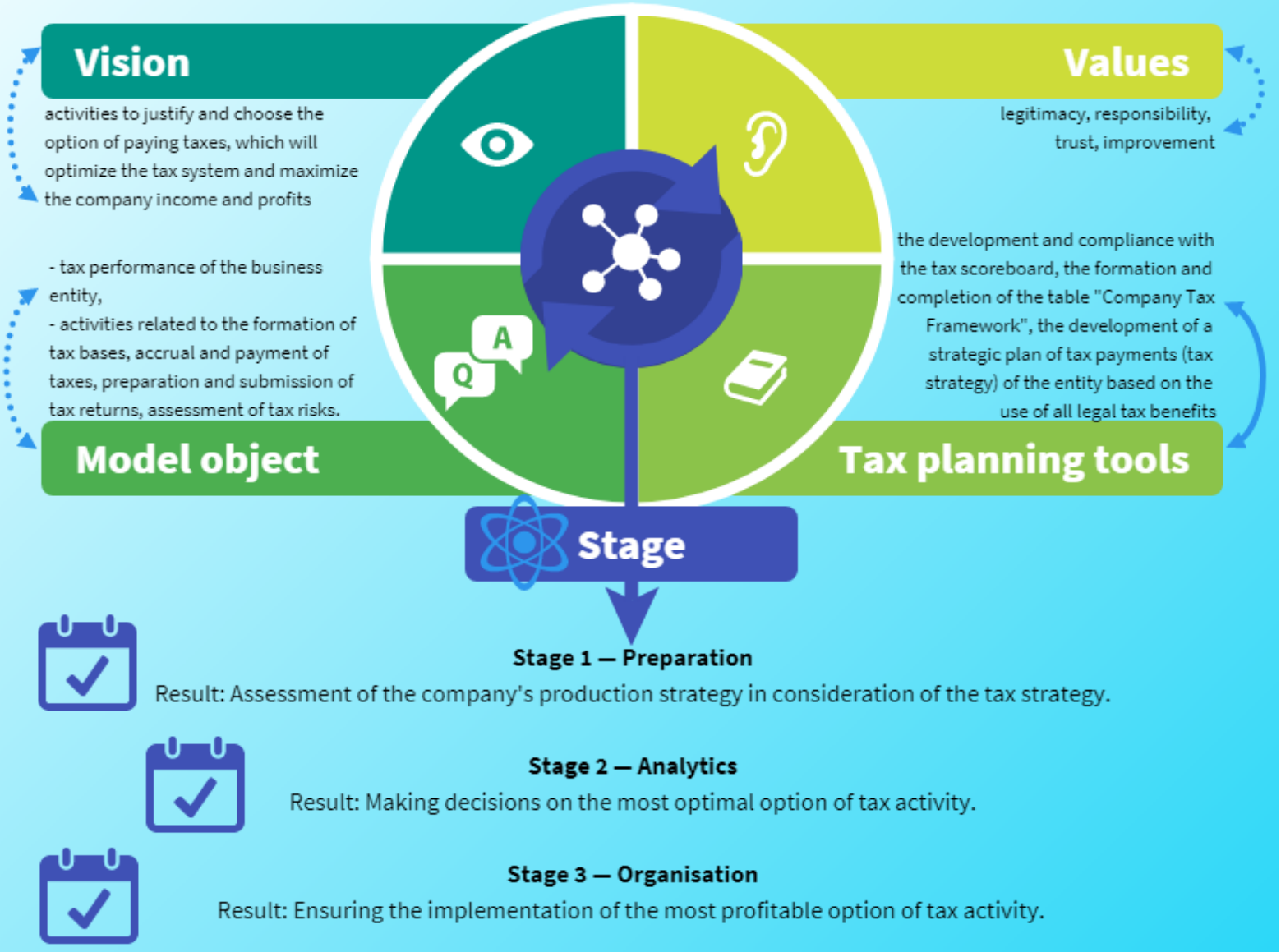

Fig. 3. Innovative model of corporate tax planning. Source: developed by the author

Implementation of the corporate tax planning model

Tax planning is a highly precise and creative process. Accuracy is that the calculation of taxes depends on the level of income, profit, and, therefore, on the level of expenditures. On the other hand, only with the right approach is tax planning a tool for legally saving assets for further business development.

The developed model of corporate tax planning (Fig. 5) is implemented on the example of companies operating in Ukrainian agribusiness. For this purpose, we have chosen Novaagro Trading House LLC, Crocus Agro LLC, Agroin agrogroup, and KVADRO group. Companies were studied for the conditions of the national tax system, tax rates and amounts of tax payments. The national taxation system, tax rates and amounts of tax payments were monitored. An assessment was provided for the dynamics of the company's activities and the scale of the taxation framework, which means the set of taxes and fees that the taxpayer is required by law to pay. Based on the results, we have developed a taxation framework for these companies. In this study, the assessment of the taxation framework means a set of taxes and fees that the taxpayer is required by law to pay. The general section of the form of the taxation framework is shown in Table 2.

The Analytical Stage deals with an assessment of alternative tax activities. At this stage, we suggest compiling a table in the form that is designed to characterize the taxation framework of the entity. We also propose to 
form typical business transactions that will be implemented by the business entity. Indicator-markers are set on the basis of analytical plans for the volume of activity, level of profitability, and marginal tax burden.

Table 2. Taxation framework of an agricultural company considering opportunity areas (general section). Source: developed by the author

\begin{tabular}{|c|c|c|c|}
\hline $\begin{array}{l}\text { Type of tax } \\
\text { and fee }\end{array}$ & Tax base & Tax rate & Notes \\
\hline $\begin{array}{l}\text { A. Income } \\
\text { tax }\end{array}$ & $\begin{array}{l}\text { Monetary expression of the } \\
\text { object of taxation }\end{array}$ & $18 \%$ & Privileges under separate taxation systems \\
\hline $\begin{array}{l}\text { B. Value- } \\
\text { added tax } \\
\text { (VAT) }\end{array}$ & $\begin{array}{l}\text { is determined by the } \\
\text { contract value, taking into } \\
\text { account national taxes and } \\
\text { fees }\end{array}$ & $20 \%$ & $\begin{array}{l}\text { Payers of the third group have the right to } \\
\text { decide independently on the VAT payment. } \\
\text { VAT exemption in case of choosing the single } \\
\text { tax rate of } 5 \% \text {. }\end{array}$ \\
\hline $\mathrm{C} \ldots$ & $\ldots$ & $\cdots$ & $\begin{array}{l}\text { Availability of benefits under certain tax } \\
\text { systems, tax exemption, choice of tax rate, etc. }\end{array}$ \\
\hline \multicolumn{4}{|c|}{ Calculations and analytical data on the company } \\
\hline \multicolumn{2}{|c|}{ Monetary assessment, thousand UAH } & $\begin{array}{l}\text { Previous } \\
\text { year }\end{array}$ & $\begin{array}{c}\text { Current } \\
\text { year }\end{array}$ \\
\hline \multicolumn{4}{|c|}{ Amount of accrued taxes and fees } \\
\hline \multicolumn{4}{|c|}{ Amount of taxes and fees paid } \\
\hline \multicolumn{4}{|l|}{ Tax arrears } \\
\hline \multicolumn{4}{|c|}{ Penalties for late payment of taxes and fees } \\
\hline \multicolumn{2}{|c|}{$\begin{array}{l}\text { Level of tax burden on the enterprise for the } \\
\text { reporting year,\% }\end{array}$} & & \\
\hline
\end{tabular}

Achieving such indicators is the subject of tax and other types of control (control of production, finance, etc.). At this stage, the company prepares a tax scoreboard for the current period, taking into account tax liabilities, tax payment deadlines and tax reporting. This plan must be consistent with the entity's overall financial plan. For the purpose of further tax control the scale of deviations of the corresponding indicators-markers is developed. Further, we propose general actions to optimize the tax activities of agricultural companies (Tab. 3).

Table 3. General actions to optimize the business tax activities, considering opportunity areas. Source: developed by the author

\begin{tabular}{|l|l|l|}
\hline \multicolumn{1}{|c|}{ Proposed measures } & \multicolumn{1}{|c|}{ Actions taken } & \multicolumn{1}{c|}{ Notes } \\
\hline $\begin{array}{l}\text { Transition to a special } \\
\text { annual period for farmers }\end{array}$ & $\begin{array}{l}\text { Submission of income tax return for } \\
\text { the first half of the year }\end{array}$ & $\begin{array}{l}\text { No mark in Field 9 Special marks of the } \\
\text { Declaration of affiliation to agricultural } \\
\text { production }\end{array}$ \\
\hline $\begin{array}{l}\text { Avoidance of the simplified } \\
\text { taxation system in } \\
\text { connection with the } \\
\text { transition to the payment of } \\
\text { other taxes and fees. }\end{array}$ & $\begin{array}{l}\text { Application for the transition no later } \\
\text { than } 10 \text { calendar days before the } \\
\text { beginning of a new calendar quarter } \\
\text { (year) and sending a tax letter stating } \\
\text { the election of a special tax period by } \\
\text { the agricultural enterprise. }\end{array}$ & $\begin{array}{l}\text { Increasing the size of the regulatory } \\
\text { monetary valuation of agricultural land } \\
\text { and single tax rates is the reason that } \\
\text { other tax systems are more profitable } \\
\text { from an economic point of view. }\end{array}$ \\
\hline $\begin{array}{l}\text { Adjustment of the financial } \\
\text { result downwards using } \\
\text { inventory charts for } \\
\text { accounting, storage of } \\
\text { seeds and finished products }\end{array}$ & $\begin{array}{l}\text { Development of accounting policies } \\
\text { for financial and tax accounting }\end{array}$ & $\begin{array}{l}\text { - improvement of accounting policy for } \\
\text { accounting and tax purposes; } \\
\text { - assessment of tax risks (possible } \\
\text { penalties): implementation of the } \\
\text { most rational - from a tax point of } \\
\text { view - placement of assets and } \\
\text { profits of the organization }\end{array}$ \\
\hline $\begin{array}{l}\text { Development of an } \\
\text { effective system of internal } \\
\text { control of tax risk } \\
\text { management }\end{array}$ & $\begin{array}{l}\text { Establishment of a corporate internal } \\
\text { tax control service }\end{array}$ & $\begin{array}{l}\text { Development or improvement of } \\
\text { corporate standards and changes in } \\
\text { the organizational structure as needed }\end{array}$ \\
\hline
\end{tabular}


The organisational stage characterizes the assessment of tax accounting and reporting (determination of the tax base, calculation of taxes and payments, accounting and tax records, preparation and submission of tax reports) and determination of the tax burden level. Control over compliance with tax legislation, control over compliance with accounting policies, assessment of the implementation of the tax plan. We have developed and proposed a map to determine the degree of effective tax planning in the corporation (Table 4).

Table 4. The map to determine the degree of effective tax planning in the corporation concerning opportunity areas. Source: developed by the author

\begin{tabular}{|c|c|c|}
\hline Questions & Answer options & Score \\
\hline $\begin{array}{l}\text { 1. Does your company have a position of tax } \\
\text { management / tax planning specialist? }\end{array}$ & $\begin{array}{l}\text { Yes } \\
\text { No } \\
\text { Functions are performed by another } \\
\text { specialist }\end{array}$ & $\begin{array}{l}3 \\
1 \\
2\end{array}$ \\
\hline 2. Does the company have an internal audit service? & $\begin{array}{l}\text { Yes } \\
\text { No } \\
\text { Functions are performed by another } \\
\text { service }\end{array}$ & $\begin{array}{l}3 \\
1 \\
2\end{array}$ \\
\hline $\begin{array}{l}\text { 3. Are there different terms of the agreements that } \\
\text { consider tax, contractual and economic consequences? }\end{array}$ & $\begin{array}{l}\text { Yes } \\
\text { No } \\
\text { Partially (for some indicators) }\end{array}$ & $\begin{array}{l}3 \\
1 \\
2\end{array}$ \\
\hline $\begin{array}{l}\text { 4. Does your company use general planning and } \\
\text { budgeting? }\end{array}$ & $\begin{array}{l}\text { Yes } \\
\text { No } \\
\text { Partially (for some indicators) }\end{array}$ & $\begin{array}{l}3 \\
1 \\
2\end{array}$ \\
\hline $\begin{array}{l}\text { 5. Does the company deal with annual tax planning of } \\
\text { its activities with respect to changes in national tax } \\
\text { legislation? }\end{array}$ & $\begin{array}{l}\text { Yes } \\
\text { No } \\
\text { Partially (for some indicators) }\end{array}$ & $\begin{array}{l}3 \\
1 \\
2\end{array}$ \\
\hline $\begin{array}{l}\text { 6. Is tax accounting enshrined in the accounting } \\
\text { policies? }\end{array}$ & $\begin{array}{l}\text { Yes } \\
\text { No } \\
\text { Partially (for some indicators) }\end{array}$ & $\begin{array}{l}3 \\
1 \\
2\end{array}$ \\
\hline $\begin{array}{l}\text { 7. Are there different accounting methods that form the } \\
\text { valuation of assets, the procedure for recognizing sales } \\
\text { revenue and write-off that are directly related to the } \\
\text { taxation of the company and its financial condition? }\end{array}$ & $\begin{array}{l}\text { Yes } \\
\text { No } \\
\text { Partially (for some indicators) }\end{array}$ & $\begin{array}{l}3 \\
1 \\
2\end{array}$ \\
\hline $\begin{array}{l}\text { 8. Does the company meet the deadlines for taxes and } \\
\text { fees to the budget and payments to extra-budgetary } \\
\text { funds? }\end{array}$ & $\begin{array}{l}\text { Yes } \\
\text { No } \\
\text { Partially (for some indicators/payments) }\end{array}$ & $\begin{array}{l}3 \\
1 \\
2\end{array}$ \\
\hline $\begin{array}{l}\text { 9. Does the company implement the most rational - } \\
\text { from a tax point of view - placement of assets and } \\
\text { profits of the organization? }\end{array}$ & $\begin{array}{l}\text { Yes } \\
\text { No } \\
\text { Partially (for some indicators) }\end{array}$ & $\begin{array}{l}3 \\
1 \\
2\end{array}$ \\
\hline $\begin{array}{l}\text { 10. Does the entity exercise the primary control over } \\
\text { legal provisions in the course of calculation and payment } \\
\text { of taxes and fees and accounting policies by using certain } \\
\text { techniques in tax accounting? }\end{array}$ & $\begin{array}{l}\text { Yes } \\
\text { No } \\
\text { Partially (for some indicators) }\end{array}$ & $\begin{array}{l}3 \\
1 \\
2\end{array}$ \\
\hline $\begin{array}{l}\text { 11. Is the implementation of the planned performance } \\
\text { indicators monitored? }\end{array}$ & $\begin{array}{l}\text { Yes } \\
\text { No }\end{array}$ & $\begin{array}{l}2 \\
1 \\
\end{array}$ \\
\hline $\begin{array}{l}\text { 12. Are targets being adjusted for internal or external } \\
\text { business conditions? }\end{array}$ & $\begin{array}{l}\text { Yes } \\
\text { No }\end{array}$ & $\begin{array}{l}2 \\
1\end{array}$ \\
\hline $\begin{array}{l}\text { 13. Are profit targets calculated with respect to the } \\
\text { company tax burden? }\end{array}$ & $\begin{array}{l}\text { Yes } \\
\text { No }\end{array}$ & $\begin{array}{l}2 \\
1 \\
\end{array}$ \\
\hline $\begin{array}{l}\text { 14. Are profit targets calculated with respect to the } \\
\text { company development strategy? }\end{array}$ & $\begin{array}{l}\text { Yes } \\
\text { No }\end{array}$ & $\begin{array}{l}2 \\
1 \\
\end{array}$ \\
\hline $\begin{array}{l}\text { 15. Is the use of the company's cash in tax flows being } \\
\text { estimated? }\end{array}$ & $\begin{array}{l}\text { Yes } \\
\text { No }\end{array}$ & $\begin{array}{l}2 \\
1\end{array}$ \\
\hline
\end{tabular}


In Table 5 we show the key designed to calculate the scores that evaluate the indicators to determine the degree of effective tax planning in the corporation considering opportunity areas

Table 5. The key for calculating the scores that evaluate the indicators to determine the degree of effective tax planning in the corporation considering opportunity areas. Source: systematized by the author

\begin{tabular}{|l|c|c|c|c|c|}
\hline Group of indicators & Question number & Range & Multiplier & $\begin{array}{c}\text { Minimum } \\
\text { score }\end{array}$ & Maximum score \\
\hline I Organisational & $1-5$ & $1-3$ & 0.3 & 1 & 3 \\
\hline II Methodological & $6-10$ & $1-3$ & 0.4 & 1 & 3 \\
\hline III Analytical & $11-15$ & $1-2$ & 0.3 & 1 & 2 \\
\hline Total score, $x$ & & & & 5 & 13.5 \\
\hline
\end{tabular}

The score for each group of indicators (I-III) is calculated by multiplying the amount by points per factor. 2) The total score is obtained by summing the indicator for each group. Evaluation of results: number of points $10<x$ $\geq 13.5$ - sufficient level; $7<x \geq 10$ - satisfactory; $5 \geq x \geq 7-$ low.

Next, the tax burden is calculated using the company's profit and according to the formula:

$$
\operatorname{PNpr}=\operatorname{PnP}: \operatorname{Pr} \times 100 \%
$$

where $\mathrm{PNpr}$ - tax burden on an individual business through the company's profit rate, \%; $\mathrm{PnP}$ - the total amount of taxes and fees paid in the reporting year; $\mathrm{Pr}-$ profit in the reporting year, thousand $\mathrm{UAH}$.

Results on the degree of effective tax planning in the corporation are presented in Table 6.

Table 6. Matrix of results on the degree of effective tax planning in the corporation. Source: summarized by the author

\begin{tabular}{|c|c|c|c|}
\hline Company & $\begin{array}{l}\text { Degree of effective tax } \\
\text { planning in the } \\
\text { corporation (max. 13.5) }\end{array}$ & $\begin{array}{l}\text { Assessment of } \\
\text { the tax burden } \\
\text { level, PNpr }\end{array}$ & $\begin{array}{l}\text { The need for tax planning in the } \\
\text { enterprise }\end{array}$ \\
\hline $\begin{array}{l}\text { Novaagro Trading } \\
\text { House LLC }\end{array}$ & 9 (sufficient) & $28 \%$ & $\begin{array}{l}\text { There is a need for tax planning and } \\
\text { opportunities }\end{array}$ \\
\hline Crocus Agro LLC & 8 (satisfactory) & $42 \%$ & \multirow{3}{*}{$\begin{array}{l}\text { Tax planning is a priority in the } \\
\text { company. After all, the level of tax } \\
\text { burden is significant and can negatively } \\
\text { affect business activity }\end{array}$} \\
\hline Agrain Agrigroup & 7 (insufficient) & $43 \%$ & \\
\hline KVADRO Group & 7 (insufficient) & $45 \%$ & \\
\hline
\end{tabular}

We also propose a scheme that reflects the participants of the tax planning system in the corporation and can be the basis for changes in the business organizational structure, corporate documents and job descriptions of those responsible (Fig. 4).

To ensure the implementation of the scheme (Fig. 4) tax planning is considered as part of the management of financial and economic activities in the company within a single strategy of economic development. In this aspect, the tax planning process will ensure the systematic use of legitimate and optimal tax methods and techniques in conditions of limited resources, the possibility of their alternative use and opportunity areas. Analytical activities and reporting of a tax planning specialist are the basis for evaluating the company's activities to develop a business plan. 


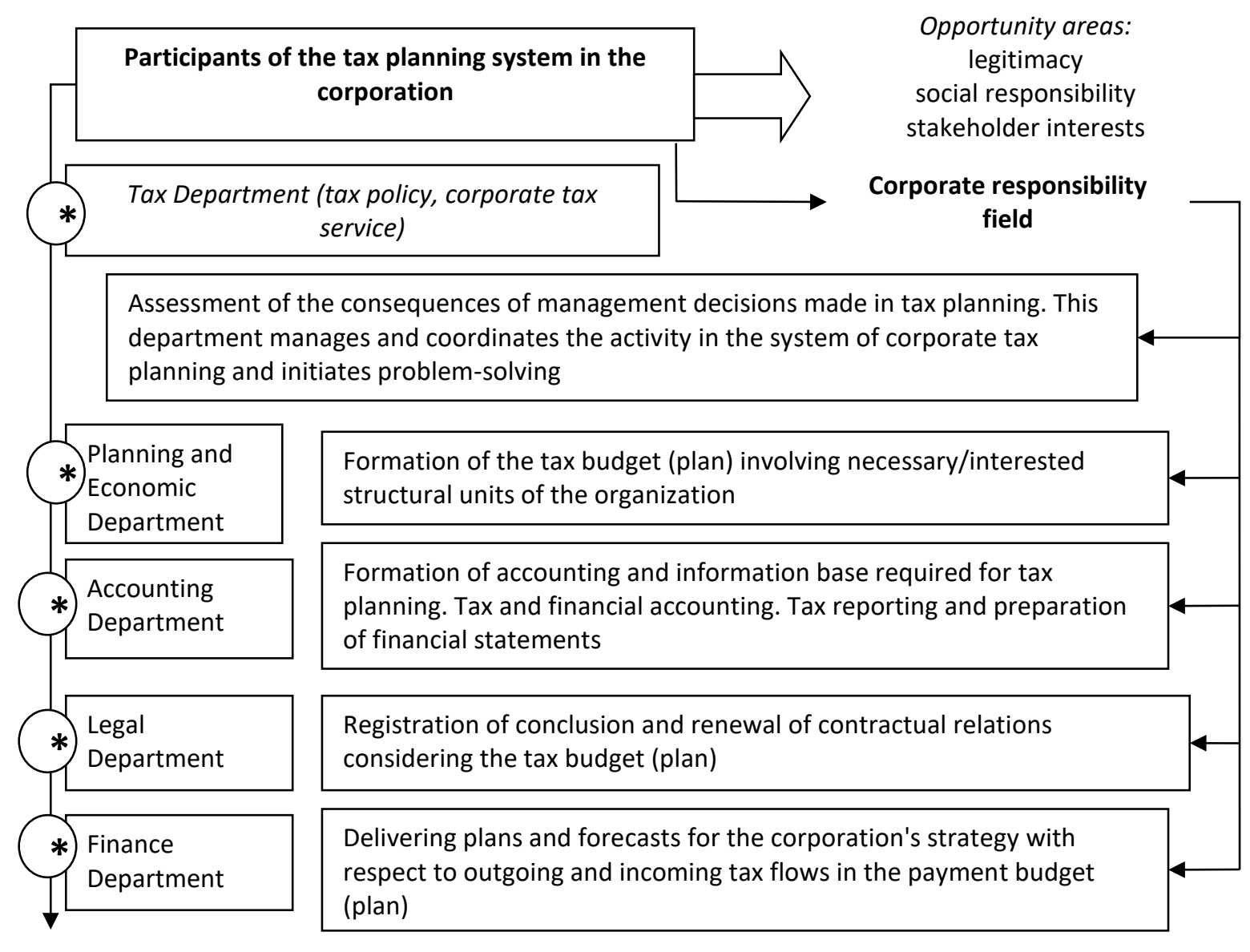

Fig. 4. Participants of the tax planning system in the corporation, the scope of their corporate responsibility considering opportunity areas. Source: developed by the author

\section{Impact}

Tax planning is a component of the strategic management of corporations, which affects the economy, increasing the company's profitability, as well as reputation through improving corporate social responsibility in the strategic perspective. The developed innovative model of tax planning is offered to the company management so that they can determine the locus of tax planning in corporate management to legally optimize tax expenditures for further business development. The implementation of such a model can be completed by both comments on changes in taxation and on their basis recommendations to the relevant departments of the enterprise, and corrective action on deviations that have arisen.

Our research shows that overly aggressive tax minimization can lead to significant adverse outcomes such as fines as well as reputational damage. Therefore, tax planning is a way to optimize tax expenditures. To do this, the company's management must support the tone at the top, which balances the goal of increasing revenue and the need for tax expenditures. Contributing to an appropriate level of thinking, management plays a key role in shaping the company's appetite for profits and ensuring decision-making on strategic tax planning.

After implementing the proposed scientific and practical development, the economic effect is expected through the preservation of working capital; increase in the overall efficiency of economic activity; growth financial stability. However, we note that the results of tax planning should be assessed not only by the amounts of reduced taxes and benefits, but also in terms of reducing possible losses and expenses that would be inevitable in business without considering the existing features of taxation.

Implementation of the tax planning model at Novaagro Trading House LLC will provide an opportunity to reduce the level of tax burden by $1.5 \%$. When implementing the model in such companies as LLC Crocus Agro, AgrogroupAgroin, and Group KVADRO, the level of their tax burden will be reduced by $1.4 \% ; 1.6 \% ; 2.5 \%$ respectively. To do this, we built a tax field, conducted tests of contractual relationships of the enterprise, and 
proposed the use of optimal forms of contracts in forecasting and determining taxable income and performance indicators to minimize the tax base for individual taxes or payments. It should also be noted that the implementation of the model of corporate tax planning involves the availability of qualified personnel who can ensure its step-by-step implementation as well as understands the scope of personal responsibility.

Since tax planning initiatives can assess both risks and benefits it should be seen as a proxy for business reputation and social responsibility.

The expected social effect from the implementation of the proposed scientific and practical development will have a positive impact on the social sphere by preventing the violation of public interest. At the same time, tax planning should consider labour and civil law which are directly related to tax optimization schemes.

What is more, the impact of tax planning on the economic and social efficiency of the corporation should be assessed on the basis of systematic and structured accounting, analytical and tax information. Given this, we consider it appropriate to form an annual taxation framework for a company and assess the level of tax burden.

\section{Conclusions}

Corporate tax planning activities are at the intersection of economics, finance, and management within the opportunity areas such as legitimacy, social responsibility, and interests of stakeholders. In recent years, there has been an increase in public awareness of corporate tax activities.

The novelty of this study includes organizational and methodological tools of tax planning, considering the opportunity areas which rest upon causal links between changes in the legislative framework, internal and external business environments. Such development is proposed in the context of continuous improvement of the corporation's management system, which is possible by expanding the competencies of employees who are responsible for tax planning. The set of tax planning tools has been improved through the taxation framework for a company considering the opportunity areas. This allows for further effective tax activities in the corporation in respect of changes in legislation, social responsibility and the interests of stakeholders.

Tax planning has been studied as a legitimate tool of tax management, which aims at optimizing tax payments to improve business performance. We concluded that in modern conditions, tax planning should be carried out constantly, regardless of the level of tax burden. However, according to the results of the survey, most respondents found the main advantage of the corporation, and that is problem-solving facilitation in terms of activity management. This means that tax planning can be effective through the effective organization of company activities. The proposed measures for the tax planning considering the opportunity areas can bring real value in financial terms. This is possible because when taxes are fully understood and expected, the corporation's management will be able to regain control over cash flows, debt payments and other liabilities.

The results of this study are relevant to improving the tax performance of corporations. This approach should be based on consistent consideration of factors, criteria and principles of conservation of corporate resources, targeted improvement of employee competencies and introduction of tax planning tools to optimize tax payments.

\section{Conflict of interest}

There are no conflicts to declare.

\section{Acknowledgments}

This research has not been supported by any external funding.

\section{References}

[1] Taxes in the world, (2021). https://visasam.ru/emigration/vybor/nalogi-v-mire.html.

[2] EuroStat, (2021). https://ec.europa.eu/eurostat/web/structural-business-statistics/overview .

[3] M. Guizani, A.N. Ajmi, The Financial Determinants of Corporate Cash Holdings: Does Sharia-Compliance Matter?, Montenegrin J. Econ. 17 (2021) 157-168. https://doi.org/10.14254/1800-5845/2021.17-3.13.

[4] B.D. Handayani, A. Rohman, A. Chariri, I.D. Pamungkas, Corporate Financial Performance on Corporate Governance Mechanism and Corporate Value: Evidence from Indonesia, Montenegrin J. Econ. 16 (2020) 161-171. https://doi.org/10.14254/1800-5845/2020.16-3.13.

[5] J.H. Wilde, R.J. Wilson, Perspectives on corporate tax planning: Observations from the past decade, J. 
Am. Tax. Assoc. 40 (2018) 63-81. https://doi.org/10.2308/atax-51993.

[6] M.C. Suchman, Managing legitimacy: Strategic and institutional approaches, Acad. Manag. Rev. 20 (1995) 571-610. https://doi.org/10.5465/amr.1995.9508080331.

[7] L. Sokolenko, T. Ostapenko, O. Kubetska, O. Portna, T. Tran, Cryptocurrency: Economic Essence and Features of Accounting, Acad. Account. Financ. Stud. J. 23 (2019) 1-6.

[8] J. Lukáč, S. Štašková, M. Meheš, Differences in the Values of Financial Indicators Depending on the Reporting System, TEM J. 10 (2021) 916-921. https://doi.org/10.18421/TEM102-54.

[9] M. Bondar, N. lershova, M. Tkachenko, V. Garkusha, S. Yavorsky, Financial decisions taking into account management reporting of enterprise, Financ. Credit Act. Probl. Theory Pract. 2 (2020) 84-92. https://doi.org/10.18371/fcaptp.v2i33.206532.

[10] C.K. Hoi, Q. Wu, H. Zhang, Is corporate social responsibility (CSR) associated with tax avoidance? Evidence from irresponsible CSR activities, Account. Rev. 88 (22013) 2025-2059. https://doi.org/10.2308/accr50544.

[11] A. Muller, A. Kolk, Responsible tax as corporate social responsibility: The case of multinational enterprises and effective tax in India, Bus. Soc. 54 (2015) 435-463. https://doi.org/10.1177/0007650312449989.

[12] N.S.. Wahab, K. Holland, Tax planning, corporate governance and equity value, Br. Account. Rev. 44 (2012) 111-124. https://doi.org/10.1016/j.bar.2012.03.005.

[13] M. De Klerk, C. De Villiers, C. Van Staden, The influence of corporate social responsibility disclosure on share prices: Evidence from the United Kingdom, Pacific Account. Rev. 27 (2015) 208-228. https://doi.org/10.1108/PAR-05-2013-0047.

[14] M.A. Desai, D. Dharmapala, Corporate tax avoidance and firm value, Rev. Econ. Stat. 91 (2009) 537-546. https://doi.org/10.1162/rest.91.3.537.

[15] N. Attig, S. El Ghoul, O. Guedham, J. Suh, Corporate social responsibility and credit ratings, J. Bus. Ethics. 117 (2013) 679-694. https://doi.org/10.1007/s10551-013-1714-2.

[16] U. Landolf, Tax and corporate responsibility, Int. Tax Rev. 29 (2006) 6-9.

[17] D. Hartnett, The Link between Taxation and Corporate Governance, 2008. https://doi.org/https://doi.org/10.1007/978-3-540-77276-7_1.

[18] A. Feller, D. Schanz, The three hurdles of tax planning: How business context, aims of tax planning, and tax manager power affect tax expense, Contemp. Account. Res. 34 (2017) 494-524. https://doi.org/10.1111/1911-3846.12278.

[19] O.V. Portna, N.Y. lershova, D.A. Tereshchenko, O.R. Kryvytska, Economic Business Partnerships Within Industry 4.0: New Technologies in Management, Montenegrin J. Econ. 17 (2021) 151-163. https://doi.org/10.14254/1800-5845/2021.17-1.11.

[20] M. Jacob, Real Effects of Corporate Taxation: A Review, Eur. Account. Rev. (2021). https://doi.org/10.1080/09638180.2021.1934055.

[21] T. Elgood, T. Fulton, M. Schutzman, Tax Function Effectiveness: The Vision for Tomorrow's Tax Function, CCH a Wolters Kluwer business, Chicago, IL, USA, 2008.

[22] M. Rashid, M.R. Noor, A. Mastuki, B. Bardai, Longitudinal Study of Corporate Tax Planning: Analysis on Companies' Tax Expense and Financial Ratios, J. Humanit. Soc. Sci. 23 (2015) 109-120.

[23] S. Princen, Determining the Impact of Taxation on Corporate Financial Decision Making, , Reflets Perspect. La Vie Économique. 3 (2012) 161-170. https://doi.org/10.3917/rpve.513.0161.

[24] N. lershova, O. Portna, V. Tretyak, K. Moskalenko, O. Vasyliev, Crisis Management: Innovative Financial and Accounting Technologies, TEM J. 10 (2021) 766-776. https://doi.org/10.18421/TEM102-34.

[25] 200 largest companies of Ukraine in 2019, https://biz.censor.net/resonance/3218608/200_nayiblshih_kompanyi_ukrani_2019_roku.

[26] Economic Code of Ukraine, (2021). https://zakon.rada.gov.ua/laws/show/436-15\#Text.

[27] State Statistics Service of Ukraine: official site, (2021). ukrstat.gov.ua.

[28] Officially about taxes. Electronic application, (2021). http://www.visnuk.com.ua/uploads/media/file/2019/08/28/b96de4824cb0b7f7ff5686c6f80cdc297642 d4b9.pdf\%0A.

[29] Tax Code of Ukraine, (2021). https//zakon.rada.gov.ua/laws/show/2755-17. 